\title{
Synthesis and formation mechanism of titanium lead carbide
}

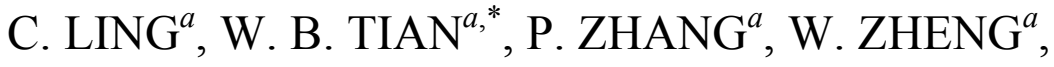 \\ Y. M. ZHANG ${ }^{b}$, Z. M. SUN ${ }^{a, *}$ \\ ${ }^{a}$ Jiangsu Key Laboratory of Advanced Metallic Materials, School of Materials Science and \\ Engineering, Southeast University, Nanjing 211189, China \\ ${ }^{b}$ Jiangsu Key Laboratory of Construction Materials, School of Materials Science and \\ Engineering, Southeast University, Nanjing 211189, China
}

Received: December 8, 2017; Revised: March 14, 2018; Accepted: March 16, 2018

(C) The Author(s) 2018. This article is published with open access at Springerlink.com

\begin{abstract}
Ti}_{2} \mathrm{PbC}$ was synthesized for the first time by pressureless reaction synthesis using $\mathrm{Ti} / \mathrm{Pb} / \mathrm{TiC}$ as starting materials at a heating rate of $2{ }^{\circ} \mathrm{C} / \mathrm{min}$ and holding at $1370{ }^{\circ} \mathrm{C}$ for $2 \mathrm{~h}$ in a tube furnace protected by Ar atmosphere. The effects of starting powders, heating rates, and holding temperatures on the formation of $\mathrm{Ti}_{2} \mathrm{PbC}$ were investigated. It was found that elementary mixture of $\mathrm{Ti} / \mathrm{Pb} / \mathrm{C}$ or higher heating rates fail to form $\mathrm{Ti}_{2} \mathrm{PbC}$. The decreased lattice parameters in the synthesized $\mathrm{Ti}_{2} \mathrm{PbC}$ indicated the existence of $\mathrm{Pb}$ vacancies in the compound. A reaction mechanism was proposed to explain the formation of $\mathrm{Ti}_{2} \mathrm{PbC}$.
\end{abstract}

Keywords: $\mathrm{Ti}_{2} \mathrm{PbC}$; MAX phase; differential scanning calorimetry (DSC); thermal stability

\section{Introduction}

MAX phases are a group of layered ternary compounds with the general formula of $\mathrm{M}_{n+1} \mathrm{AX}_{n}$ (M: early transition metal; A: IIIA- or IVA-group element; X: C and/or $\mathrm{N} ; n=1-3$ ), which combine properties of ceramics and metals, such as low density, high elastic modulus, excellent self-lubricating property, and high electrical and thermal conductivities [1-3]. Less than a hundred of MAX phases (exclusive of solid solutions) have been obtained experimentally so far, although the number of the potential MAX phases is considerably larger. The research for further control over the properties of MAX phases with new functionalities has

* Corresponding authors.

E-mail: W. B. Tian, wbtian@seu.edu.cn;

Z.M.Sun, zmsun@seu.edu.cn resulted in an increased interest in MAX phase synthesis $[1,4]$. $\mathrm{Ti}_{2} \mathrm{PbC}$ is expected to be similar to other MAX phases, and may show unique functionality as the buffer layer in lead acid batteries [5-7]. In addition, the calculation by the first-principle suggests that the bonding between $\mathrm{Ti}$ and $\mathrm{Pb}$ is relatively weak and the diffusion coefficient of $\mathrm{Pb}$ element is high [8], indicating that $\mathrm{Ti}_{2} \mathrm{PbC}$ could be an ideal raw material to prepare MXene, a newly emerging group of two-dimensional materials [9]. It should be pointed out that $\mathrm{Pb}$ is an element detrimental to human's health but also of great value in industrial application irreplaceably.

The fabrication of $\mathrm{Ti}_{2} \mathrm{PbC}$ was reported only once by Jeitschko et al. [10] in 1964 by heating a TiC/Ti/Pb mixture to $850{ }^{\circ} \mathrm{C}$ for up to $600 \mathrm{~h}$ in vacuum. In this original paper, Jeitschko et al. measured the lattice constant and density of $\mathrm{Ti}_{2} \mathrm{PbC}$. The authors also described the structure of the $\mathrm{Ti}_{2} \mathrm{PbC}$ that contains A-site vacancies intrinsically. 
Some researchers tried to synthesize $\mathrm{Ti}_{2} \mathrm{PbC}$ at $850{ }^{\circ} \mathrm{C}$ as Jeitschko et al. did [5], but the synthesized $\mathrm{Ti}_{2} \mathrm{PbC}$ powders contained a mass of impurities, such as TiC, $\mathrm{Ti}-\mathrm{Pb}$ compounds, which were resulted from the low synthesizing temperature. Except for this, there was no related literature on the synthesis of $\mathrm{Ti}_{2} \mathrm{PbC}$ further according to the authors' knowledge.

Various processes were used to fabricate other MAX phase powders, including solid-liquid reaction [11], microwave hybrid heating [12], fluctuation synthesis [13], self-propagating high-temperature synthesis [14], etc. However, purity of the synthesized powders via these methods is still not satisfied. Previously, almost single-phase $\mathrm{Ti}_{2} \mathrm{SnC}$ powders were synthesized through a simple pressureless reaction synthesis process of $\mathrm{Ti} / \mathrm{Sn} / \mathrm{TiC}$ mixed powders at $1200{ }^{\circ} \mathrm{C}$ in vacuum for 15 min [15]. Using the similar method, we have prepared high-purity MAX powders, including $\mathrm{Ti}_{3} \mathrm{AlC}_{2}, \mathrm{Ti}_{3} \mathrm{SiC}_{2}$, $\mathrm{Ti}_{2} \mathrm{AlC}[16,17]$, etc. The objectives of the present work, therefore, are to explore the possibility of synthesizing high-purity $\mathrm{Ti}_{2} \mathrm{PbC}$ by a pressureless reaction synthesis method, to optimize the processing parameters, and to understand the mechanism of the $\mathrm{Ti}_{2} \mathrm{PbC}$ formation path.

\section{Experimental procedures}

Ti (300 mesh, $\geqslant 99.9 \%$ purity), $\mathrm{Pb}$ (300 mesh, $\geqslant$ $99.95 \%$ purity), C (625 mesh, $\geqslant 99.0 \%$ purity), and TiC (1340-2000 mesh, $\geqslant 99.95 \%$ purity) powders were used as starting materials. Table 1 shows the compositions and synthesis conditions, where $\mathrm{Ti} / \mathrm{Pb} / \mathrm{C}$ (molar ratio: 2:1.2:1) and $\mathrm{Ti} / \mathrm{Pb} / \mathrm{TiC}$ (molar ratio: 1:1.2:1, 1:1.0:1, 1:0.8:1) were used as starting powders and mixed in plastic jar for $24 \mathrm{~h}$.

Table 1 Compositions of raw materials and synthesis parameters for $\mathrm{Ti}_{2} \mathrm{PbC}$ fabrication

\begin{tabular}{|c|c|c|c|}
\hline Code & Raw material & Synthesis temperature & Heating rate $\left({ }^{\circ} \mathrm{C} / \mathrm{min}\right)$ \\
\hline A & \multirow{2}{*}{$2 \mathrm{Ti} / 1.2 \mathrm{~Pb} / 1 \mathrm{C}$} & \multirow{4}{*}{$1370{ }^{\circ} \mathrm{C}$} & 10 \\
\hline $\mathrm{B}$ & & & 2 \\
\hline $\mathrm{C}$ & \multirow{5}{*}{$1 \mathrm{Ti} / 1.2 \mathrm{~Pb} / 1 \mathrm{TiC}$} & & 10 \\
\hline $\mathrm{D}$ & & & \multirow{6}{*}{2} \\
\hline $\mathrm{E}$ & & $1200{ }^{\circ} \mathrm{C}$ & \\
\hline $\mathrm{F}$ & & $1000{ }^{\circ} \mathrm{C}$ & \\
\hline G & & $850{ }^{\circ} \mathrm{C}$ & \\
\hline $\mathrm{H}$ & $1 \mathrm{Ti} / 1.0 \mathrm{~Pb} / 1 \mathrm{TiC}$ & \multirow{2}{*}{$1370{ }^{\circ} \mathrm{C}$} & \\
\hline I & $1 \mathrm{Ti} / 0.8 \mathrm{~Pb} / 1 \mathrm{TiC}$ & & \\
\hline
\end{tabular}

Powder mixtures were put into alumina crucibles that were placed in a graphite crucible, and then pressureless sintered at different temperatures for $2 \mathrm{~h}$ in $\mathrm{Ar}$ atmosphere to prepare $\mathrm{Ti}_{2} \mathrm{PbC}$. Two kinds of heating rates were applied: a high rate of $10{ }^{\circ} \mathrm{C} / \mathrm{min}$, and a low heating rate of $2{ }^{\circ} \mathrm{C} / \mathrm{min}$, from room temperature to the target temperature.

The constituent phase information and microstructure of prepared $\mathrm{Ti}_{2} \mathrm{PbC}$ samples were analyzed by $\mathrm{X}$-ray diffraction (XRD, D8-Discover, Bruker) and by scanning electron microscope (SEM, XL 30, FEI-Philips) equipped with energy dispersive spectrometer (EDS). To clarify the possible reactions, the specific heat was determined by differential scanning calorimetry (DSC, 04 F3, Pegasus) in the temperature range of room temperature to $1000{ }^{\circ} \mathrm{C}$.

\section{Results and discussion}

\section{1 Optimization of processing parameters for $\mathrm{Ti}_{2} \mathrm{PbC}$ synthesis}

Samples A and B were synthesized from $2 \mathrm{Ti} / 1.2 \mathrm{~Pb} / 1 \mathrm{C}$ powders at $1370{ }^{\circ} \mathrm{C}$ for $2 \mathrm{~h}$ at different heating rates of 10 and $2{ }^{\circ} \mathrm{C} / \mathrm{min}$, respectively. Their XRD patterns are respectively shown in Figs. 1(a) and 1(b), where no $\mathrm{Ti}_{2} \mathrm{PbC}$ phase is identified in both samples $\mathrm{A}$ and $\mathrm{B}$. It suggests that $\mathrm{Ti}_{2} \mathrm{PbC}$ is difficult to form from the starting powders of $2 \mathrm{Ti} / 1.2 \mathrm{~Pb} / 1 \mathrm{C}$, at either of the heating rates applied.

Using $1 \mathrm{Ti} / 1.2 \mathrm{~Pb} / 1 \mathrm{TiC}$ instead of $2 \mathrm{Ti} / 1.2 \mathrm{~Pb} / 1 \mathrm{C}$ as starting materials, some obvious different results could be found. Although similar results are reached when heated at high rate of $10{ }^{\circ} \mathrm{C} / \mathrm{min}$ (sample C, Fig. 1(c)), $\mathrm{Ti}_{2} \mathrm{PbC}$ phase becomes the predominant one when heated at a low rate of $2{ }^{\circ} \mathrm{C} / \mathrm{min}$ and held at $1370{ }^{\circ} \mathrm{C}$ for $2 \mathrm{~h}$, as shown in Fig. 1(d) (sample D). It is well known that, during the synthesis of $\mathrm{Ti}_{3} \mathrm{SiC}_{2}$ and $\mathrm{Ti}_{3} \mathrm{AlC}_{2}$ from elemental starting powders, there exists always a combustion reaction between $\mathrm{Ti}$ and $\mathrm{C}[18,19]$. This reaction releases a large amount of heat, which results in a sharp temperature pike in the synthesizing process. Similarly, such temperature pike would occur in the preparation of $\mathrm{Ti}_{2} \mathrm{PbC}$, leading to its decomposition. Using the $\mathrm{TiC}$ powders instead of $\mathrm{Ti}$ and $\mathrm{C}$ powder mixture prevents the $\mathrm{Ti}-\mathrm{C}$ combustion reaction, lowering the system temperature and favoring the formation of $\mathrm{Ti}_{2} \mathrm{PbC}$.

It is obvious that the same starting materials in 
sample C and sample D do not lead to the same synthesized product due to the difference in heating rate. As shown in Fig. 1(c), with an increase in heating rate to $10{ }^{\circ} \mathrm{C} / \mathrm{min}$, sample $\mathrm{C}$ synthesized from $\mathrm{Ti} / \mathrm{Pb} / \mathrm{TiC}$, the same with sample $\mathrm{D}$, contains no $\mathrm{Ti}_{2} \mathrm{PbC}$ phase. Low heating rate allows long reacting time between raw materials and favors a thermodynamic equilibrium, leading to the formation of $\mathrm{Ti}_{2} \mathrm{PbC}$. A high heating rate is likely to induce over-heating and the equilibrium is hard to reach.

Accordingly, all the following samples E-I were syntheszied from $\mathrm{Ti} / \mathrm{Pb} / \mathrm{TiC}$ with a heating rate of $2{ }^{\circ} \mathrm{C} / \mathrm{min}$.

Samples D, E, F, and G were synthesized from $1 \mathrm{Ti} / 1.2 \mathrm{~Pb} / 1 \mathrm{TiC}$ at different synthesis temperatures for $2 \mathrm{~h}$ at a heating rate of $2{ }^{\circ} \mathrm{C} / \mathrm{min}$. The corresponding XRD results are shown in Fig. 2. When synthesized at $850{ }^{\circ} \mathrm{C}, \mathrm{Ti}_{2} \mathrm{PbC}$ phase has already formed, but $\mathrm{TiC}$ and $\mathrm{Pb}$ impurities are the predominant phases. In addition, $\mathrm{Ti}_{4} \mathrm{~Pb}$ phase is formed, which may be a reaction product at low temperature, because the reaction between liquid $\mathrm{Pb}$ and Ti occurs at temperatures above $400{ }^{\circ} \mathrm{C}[20,21]$.

When the synthesis temperature increases to $1000{ }^{\circ} \mathrm{C}$, $\mathrm{Ti}_{2} \mathrm{PbC}$ becomes predominant, and its content increases with increasing synthesis temperature. However, TiC and $\mathrm{Pb}$ impurities always accompany $\mathrm{Ti}_{2} \mathrm{PbC}$ even when the synthesis temperature increases to $1200{ }^{\circ} \mathrm{C}$. $\mathrm{Ti}_{2} \mathrm{PbC}$ becomes the dominant phase with small amount of $\mathrm{Pb}$ when sintered at $1370{ }^{\circ} \mathrm{C}$. Apparently, for the starting materials of $1 \mathrm{Ti} / 1.2 \mathrm{~Pb} / 1 \mathrm{TiC}$, the over

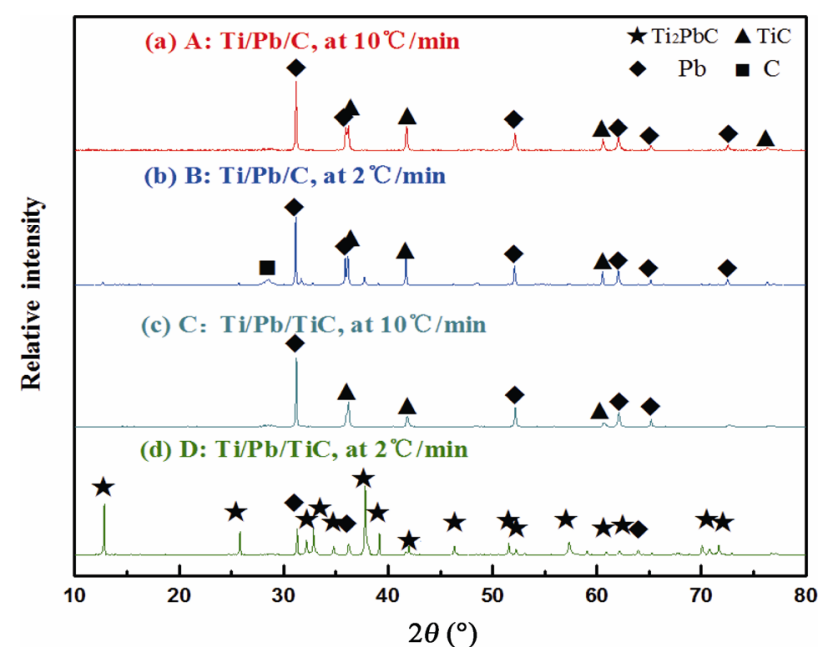

Fig. 1 XRD patterns of (a) sample $A$ from $\mathrm{Ti} / \mathrm{Pb} / \mathrm{C}$ at $10{ }^{\circ} \mathrm{C} / \mathrm{min}$; (b) sample $\mathrm{B}$ from $\mathrm{Ti} / \mathrm{Pb} / \mathrm{C}$ at $2{ }^{\circ} \mathrm{C} / \mathrm{min}$; (c) sample $\mathrm{C}$ from $\mathrm{Ti} / \mathrm{Pb} / \mathrm{TiC}$ at $10{ }^{\circ} \mathrm{C} / \mathrm{min}$; (d) sample $\mathrm{D}$ from $\mathrm{Ti} / \mathrm{Pb} / \mathrm{TiC}$ at $2{ }^{\circ} \mathrm{C} / \mathrm{min}$. All samples were synthesized at $1370{ }^{\circ} \mathrm{C}$. stoichiometric $\mathrm{Pb}$ concentration is likely the reason why $\mathrm{Pb}$ always remains in the synthesized materials. Consequently, we decreased the molar ratios of $\mathrm{Pb}$ in the starting mixtures to prepare high-purity $\mathrm{Ti}_{2} \mathrm{PbC}$ powders.

Samples D, H, and I were synthesized from $1 \mathrm{Ti} / x \mathrm{~Pb} / 1 \mathrm{TiC}$, and $x$ value is ranged from 0.8 to 1.2 , respectively, with their XRD patterns shown in Fig. 3. $\mathrm{Ti}_{2} \mathrm{PbC}$ is the main phase in all samples, while $\mathrm{Pb}$ still remains in the final products. And the intensity of characteristic peaks of $\mathrm{Pb}$ decreases gradually with the decreasing $x$ values.

$\mathrm{Pb}$ is still detected when using a stoichiometric composition of $1 \mathrm{Ti} / 0.8 \mathrm{~Pb} / 1 \mathrm{TiC}$ to prepare $\mathrm{Ti}_{2} \mathrm{PbC}$,

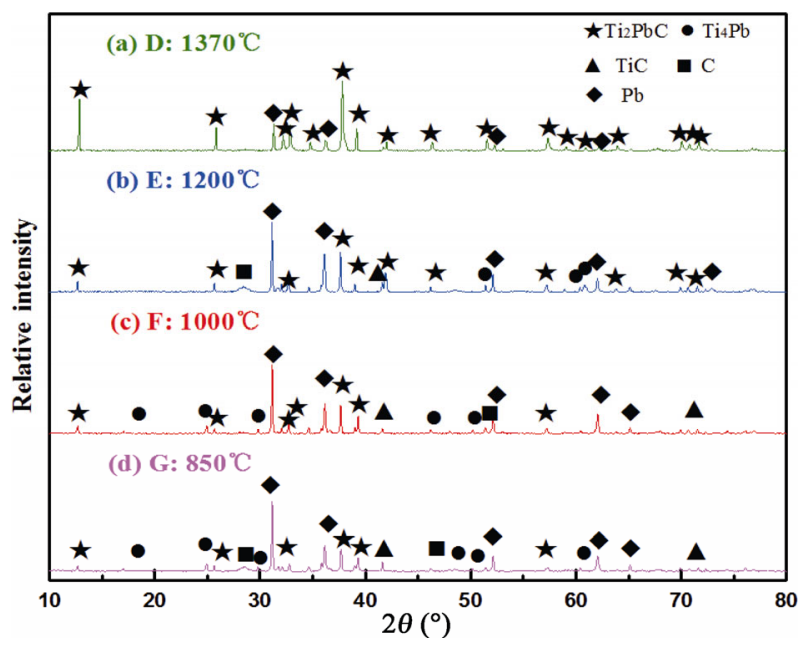

Fig. 2 XRD patterns of samples $D-G$ synthesized from $\mathrm{Ti} / \mathrm{Pb} / \mathrm{TiC}$ at a heating rate of $2{ }^{\circ} \mathrm{C} / \mathrm{min}$ at (a) $1370{ }^{\circ} \mathrm{C}$, (b) $1200{ }^{\circ} \mathrm{C}$, (c) $1000{ }^{\circ} \mathrm{C}$, and (d) $850{ }^{\circ} \mathrm{C}$.

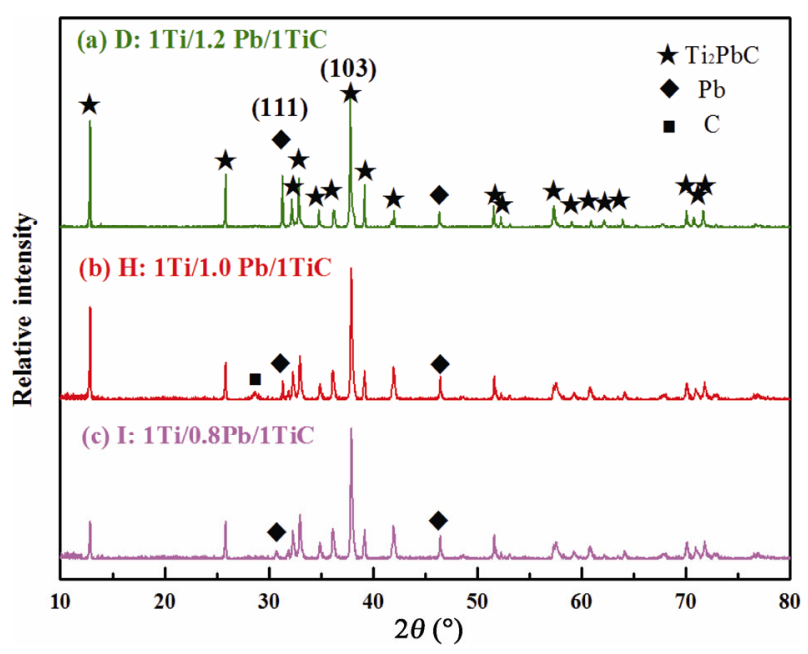

Fig. 3 XRD patterns of samples D, H, and I synthesized at $1370{ }^{\circ} \mathrm{C}$ with a heating rate of $2{ }^{\circ} \mathrm{C} / \mathrm{min}$ from $1 \mathrm{Ti} / x \mathrm{~Pb} /$ $1 \mathrm{TiC}$, where $x$ is (a) 1.2, (b) 1.0, and (c) 0.8 . 
suggesting the possible formation of $\mathrm{Pb}$ vacancies in the crystal structure of $\mathrm{Ti}_{2} \mathrm{PbC}$. This hypothesis could be verified from two aspects. First, the monovacancy formation energy for $\mathrm{Pb}$ in $\mathrm{Ti}_{2} \mathrm{PbC}$ is reported to be $0.99 \mathrm{eV}$, which is much smaller than those of other A-site metals, such as $\mathrm{Ga}(2.59 \mathrm{eV})$, In $(2.19 \mathrm{eV}), \mathrm{Sn}$ $(2.08 \mathrm{eV})$, and $\mathrm{Cd}(1.62 \mathrm{eV})$ [8]. Second, the lattice parameters of $\mathrm{Ti}_{2} \mathrm{PbC}$ measured by XRD also confirm the existence of $\mathrm{Pb}$ vacancies. Table 2 lists the previously reported and the presently measured lattice parameters of $\mathrm{Ti}_{2} \mathrm{PbC}$. We can find that $a$ and $c$ of $\mathrm{Ti}_{2} \mathrm{PbC}$ in present study are smaller than those in the literature. Especially the decreased amount in $c$ axis $(-1.5 \%)$ is much larger than that in $a$ axis $(-0.7 \%)$, indicating the possible existence of $\mathrm{Pb}$ vacancies.

We used EDS to measure the $\mathrm{Ti}: \mathrm{Pb}$ ratio of five random areas in sample $\mathrm{D}$ and obtained the average value. As shown in Fig. 4, the Ti: $\mathrm{Pb}$ ratio is 2.17:1, indicating the existence of $\mathrm{Pb}$ vacancies in $\mathrm{Ti}_{2} \mathrm{PbC}$ that has also been mentioned by Jeitschko et al. [10].

\section{2 Morphology of the synthesized $\mathrm{Ti}_{2} \mathrm{PbC}$ powders}

Figures 5(a)-5(d) show the representative morphologies of the as-prepared $\mathrm{Ti}_{2} \mathrm{PbC}$ powders from $\mathrm{Ti} / \mathrm{Pb} / \mathrm{TiC}$ at $1370{ }^{\circ} \mathrm{C}$ at $2{ }^{\circ} \mathrm{C} / \mathrm{min}$ for $2 \mathrm{~h}$ (sample D). $\mathrm{Ti}_{2} \mathrm{PbC}$

Table 2 Lattice parameters of $\mathrm{Ti}_{2} \mathrm{PbC}$ reported in the literature and measured from XRD results in this study for samples synthesized from $1 \mathrm{Ti} / 1.0 \mathrm{~Pb} / 1 \mathrm{TiC}$

\begin{tabular}{cll}
\hline \multirow{2}{*}{ Data resource } & \multicolumn{2}{c}{ Lattice parameter $(\AA)$} \\
\cline { 2 - 3 } & \multicolumn{1}{c}{$a$} & \multicolumn{1}{c}{$c$} \\
\hline Previous report & $3.222[10]$ & $13.99[10]$ \\
Present study & 3.201 & 13.78 \\
\hline
\end{tabular}

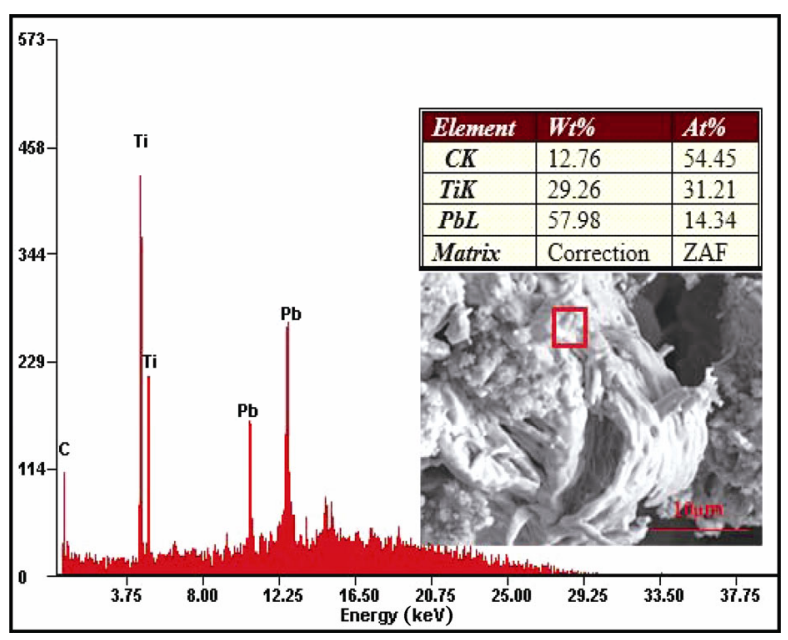

Fig. 4 EDS spectra from the marked area of sample D.

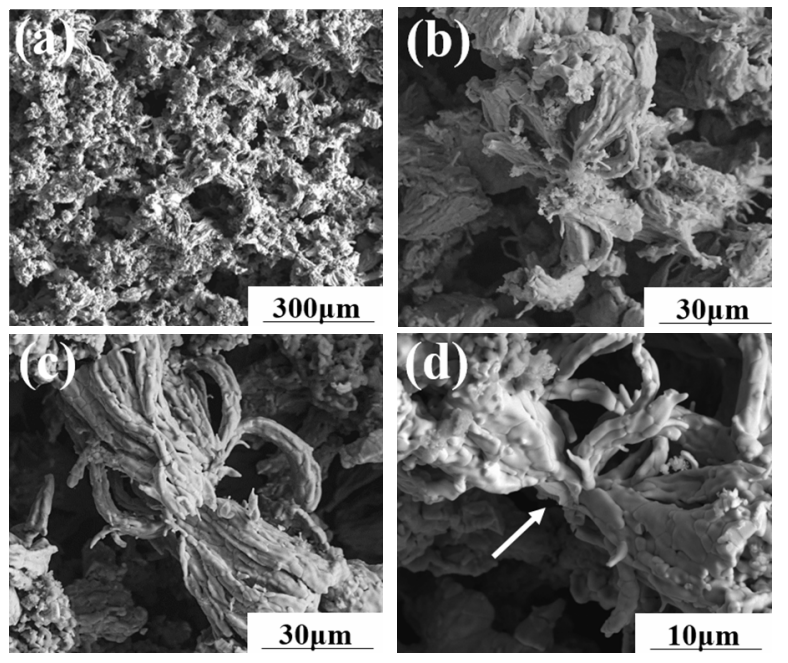

Fig. $5 \mathrm{SEM}$ images of $\mathrm{Ti}_{2} \mathrm{PbC}$ powders synthesized from $\mathrm{Ti} / \mathrm{Pb} / \mathrm{TiC}$ after synthesis at $1370{ }^{\circ} \mathrm{C}$ at $2{ }^{\circ} \mathrm{C} / \mathrm{min}$ for $2 \mathrm{~h}$ (sample $\mathrm{D}$ ): (a) the as-prepared $\mathrm{Ti}_{2} \mathrm{PbC}$ powders, (b) the flower-like $\mathrm{Ti}_{2} \mathrm{PbC}$, (c) the bowknot-like $\mathrm{Ti}_{2} \mathrm{PbC}$, and (d) higher magnification images of the bowknot.

particles display mainly flower-like or bowknot-like shapes, as shown in Fig. 5(a) and enlarged in Fig. 5(b) and Fig. 5(c), respectively.

At a higher magnification, we can see that the rod-like $\mathrm{Ti}_{2} \mathrm{PbC}$ is gathered to form the wings of bowknot in Fig. 5(d). The layered microstructure in the middle of the bowknot where the arrowhead points, is a typical feature of MAX phase, shown in Fig. 5(d). Such layered grains are identified to be $\mathrm{Ti}_{2} \mathrm{PbC}$ with $\mathrm{EDS}$ results (not shown).

Note that all micrographs were taken from the surface areas of the sample, where the $\mathrm{Ti}_{2} \mathrm{PbC}$ grains may grow freely. Carefully observing the $\mathrm{Ti}_{2} \mathrm{PbC}$ grains in Fig. $5(\mathrm{~d})$, we found that they generally grow into elongated shapes, suggesting that $\mathrm{Ti}_{2} \mathrm{PbC}$ shows an anisotropic growth behavior. This feature is attributed to the varied grain growth rate in different crystal planes, similar to other MAX phases [22]. Furthermore, the liquid phase formed from low-melting-point $\mathrm{Pb}$ during synthesis would benefit the anisotropic growth of $\mathrm{Ti}_{2} \mathrm{PbC}$ grains. This supposition is further confirmed by the much coarser $\mathrm{Ti}_{2} \mathrm{PbC}$ grains in the $1 \mathrm{Ti} / 1.2 \mathrm{~Pb} / 1 \mathrm{TiC}$ reaction system (not shown), where excessive $\mathrm{Pb}$ provides more liquid amount during synthesizing process.

\section{3 Reaction mechanism for formation of $\mathrm{Ti}_{2} \mathrm{PbC}$}

Figure 6 presents the DSC curve of a mixture of $1 \mathrm{Ti} / 1.0 \mathrm{~Pb} / 1 \mathrm{TiC}$ powders in the temperature range from room temperature to $1000{ }^{\circ} \mathrm{C}$ at a heating rate of $2{ }^{\circ} \mathrm{C} / \mathrm{min}$. 


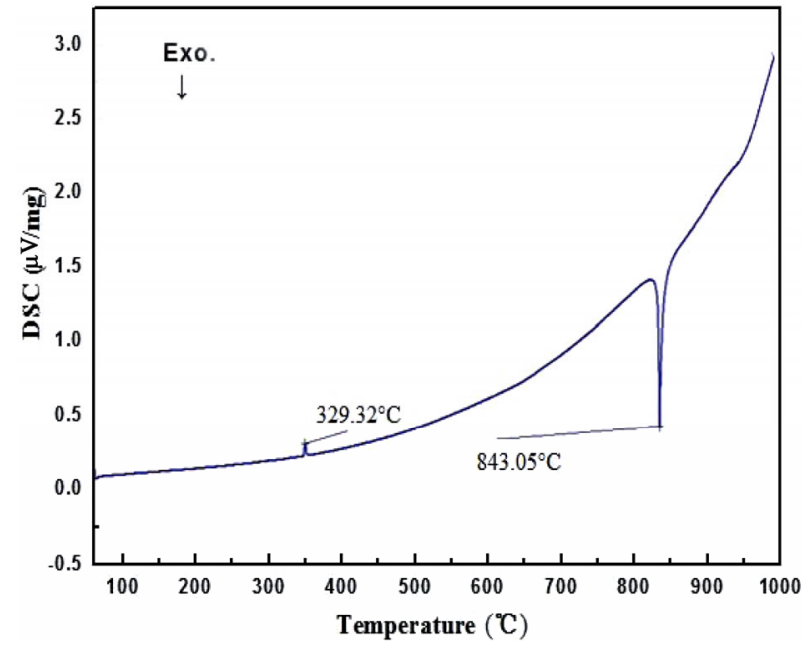

Fig. 6 DSC curve of a mixture of $\mathrm{Ti} / \mathrm{Pb} / \mathrm{TiC}$ powders.

The endothermic peak at $329.32{ }^{\circ} \mathrm{C}$ corresponds to the melting of $\mathrm{Pb}$. The exothermic peak at $843.05{ }^{\circ} \mathrm{C}$ may be associated with the reactions between the $\mathrm{Ti}-\mathrm{Pb}$ compounds and $\mathrm{TiC}$ to form $\mathrm{Ti}_{2} \mathrm{PbC}$. According to the XRD result (Fig. 2(d)) and Ti-Pb binary diagram, intermetallic compound like $\mathrm{Ti}_{4} \mathrm{~Pb}$ is surely formed at temperatures between 400 and $850{ }^{\circ} \mathrm{C}$. The possibly exothermic peaks related to the reactions between $\mathrm{Ti}$ and $\mathrm{Pb}$ are negligible in the DSC curve. This may be attributed to the mild reactions between $\mathrm{Ti}$ and $\mathrm{Pb}$ occurred in a relatively wide temperature range, dispersing the corresponding heat pike.

Based on the DSC analysis and XRD results, a reaction mechanism was put forward. For the homogeneous powder mixture of $\mathrm{Ti} / \mathrm{Pb} / \mathrm{TiC}, \mathrm{Pb}$ first starts to melt as temperature increases to be above $328{ }^{\circ} \mathrm{C}$. Then $\mathrm{Ti}$ reacts with $\mathrm{Pb}$ to form $\mathrm{Ti}-\mathrm{Pb}$ compounds with increasing temperature. Once the temperature reaches $850{ }^{\circ} \mathrm{C}$, reactions between the $\mathrm{Ti}-\mathrm{Pb}$ compounds and $\mathrm{TiC}$ occur to form $\mathrm{Ti}_{2} \mathrm{PbC}$ phase, which may proceed on $\mathrm{TiC}$ surfaces and be promoted by the liquid $\mathrm{Pb}$ environment. Thus, the reaction sequence during the synthesis of $\mathrm{Ti}, \mathrm{Pb}$, and TiC powders is as follows:

$$
\begin{gathered}
\mathrm{Pb}(\mathrm{s}) \stackrel{\sim 328^{\circ} \mathrm{C}}{\longrightarrow} \mathrm{Pb}(\mathrm{l}) \\
\mathrm{Pb}(\mathrm{l})+\mathrm{Ti}(\mathrm{s}) \rightarrow \mathrm{Ti}_{4} \mathrm{~Pb} \\
\mathrm{Ti}_{4} \mathrm{~Pb}+\mathrm{Pb}+\mathrm{TiC} \stackrel{\sim 850^{\circ} \mathrm{C}}{\longrightarrow} \mathrm{Ti}_{2} \mathrm{PbC}
\end{gathered}
$$

It is interesting to find that the prepared $\mathrm{Ti}_{2} \mathrm{PbC}$ powders are easily decomposed during the following planetary ball milling. $\mathrm{Ti}_{2} \mathrm{PbC}$ powders and corresponding zirconia balls (with the ball-to-powder mass ratio of

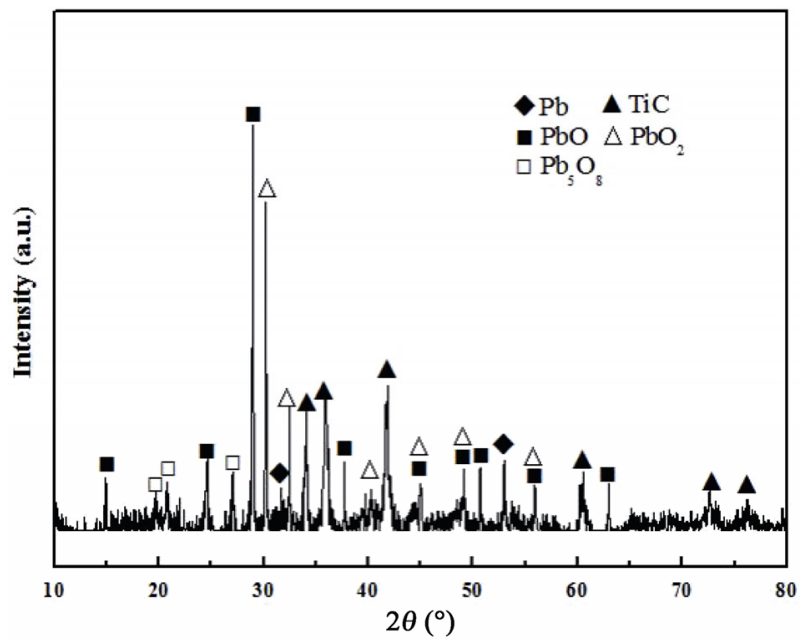

Fig. 7 XRD pattern of sample D after ball milling.

10/1) were placed in stainless steel jars. The milling process was performed for $1 \mathrm{~h}$ in air, at $500 \mathrm{r} / \mathrm{min}$ by a ND7-1L planetary ball mill. The corresponding XRD pattern shows that no $\mathrm{Ti}_{2} \mathrm{PbC}$ but $\mathrm{TiC}$ and $\mathrm{Pb}$ are found, with $\mathrm{PbO}$ and $\mathrm{PbO}_{2}$ as minor phases (as shown in Fig. 7). The decomposition of $\mathrm{Ti}_{2} \mathrm{PbC}$ phase is mainly attributed to the weak Ti-Pb bonding [23,24], which is consistent with the results of lattice parameter calculation (Table 2), namely easy formation of $\mathrm{Pb}$ vacancies. Decomposition of MAX phases, induced by the outward diffusion of A element from the layered structure under certain conditions, is well reported. When $\mathrm{Ti}_{3} \mathrm{SiC}_{2}$ is placed in a harsh environment such as molten $\mathrm{Al}$ [25-27], Si atoms migrate outward, leaving the $\mathrm{TiC}_{x}$ layers behind. It is also confirmed that $\mathrm{Ti}_{3} \mathrm{AlC}_{2}$ decomposes at $1450{ }^{\circ} \mathrm{C}$ in vacuum by the outward diffusion of $\mathrm{Al}$ atoms and can be corroded in molten $\mathrm{KOH}$ at $700{ }^{\circ} \mathrm{C}[28,29]$. This work reveals another manner of decomposition of an MAX phase, by ball milling.

\section{Conclusions}

$\mathrm{Ti}_{2} \mathrm{PbC}$ powders were successfully synthesized for the first time by pressureless synthesis. $\mathrm{Ti}_{2} \mathrm{PbC}$ was obtained by synthesizing $\mathrm{Ti} / \mathrm{Pb} / \mathrm{TiC}$ at a low heating rate of $2{ }^{\circ} \mathrm{C} / \mathrm{min}$. Starting materials of $\mathrm{Ti} / \mathrm{Pb} / \mathrm{C}$ or higher heating rates resulted in the failure of $\mathrm{Ti}_{2} \mathrm{PbC}$ synthesis. The decreased lattice parameters in the synthesized $\mathrm{Ti}_{2} \mathrm{PbC}$ indicated the existence of $\mathrm{Pb}$ vacancies in the compound. A possible reaction mechanism was proposed to explain the formation of $\mathrm{Ti}_{2} \mathrm{PbC}$, namely $\mathrm{Pb}$ melts at $328^{\circ} \mathrm{C}$ and $\mathrm{Ti}-\mathrm{Pb}$ compounds 
form by the reactions between $\mathrm{Ti}$ and liquid $\mathrm{Pb}$, and subsequently $\mathrm{Ti}_{2} \mathrm{PbC}$ forms through the reaction between $\mathrm{Ti}-\mathrm{Pb}$ compounds and $\mathrm{TiC}$. It is the first report on the decomposition of $\mathrm{Ti}_{2} \mathrm{PbC}$ into $\mathrm{TiC}$ and $\mathrm{Pb}$ during ball milling.

\section{Acknowledgements}

This research is supported by the grants from National Natural Science Foundation (Nos. 51731004, 51501038, and 51671054) and the Fundamental Research Funds for the Central Universities in China.

\section{References}

[1] Sun ZM. Progress in research and development on MAX phases: A family of layered ternary compounds. Int Mater Rev 2011, 56: 143-166.

[2] Barsoum MW. The $\mathrm{M}_{\mathrm{N}+1} \mathrm{AX} X_{\mathrm{N}}$ phases: A new class of solids: Thermodynamically stable nanolaminates. Prog Solid State Ch 2000, 28: 201-281.

[3] $\mathrm{Xu} \mathrm{L}, \mathrm{Zhu} \mathrm{D}$, Grasso S, et al. Effect of texture microstructure on tribological properties of tailored $\mathrm{Ti}_{3} \mathrm{AlC}_{2}$ ceramic. J Adv Ceram 2017, 6: 120-128.

[4] Arróyave R, Talapatra A, Duong T, et al. Does aluminum play well with others? Intrinsic Al-A alloying behavior in 211/312 MAX phases. Mater Res Lett 2017, 5: 170-178.

[5] Lara-Curzio E, An K, Kiggans Jr. JO, et al. Lightweight, durable lead-acid batteries. U.S. Patent 8,017,273. 2011.

[6] Sun ZM, Barsoum MW. Spontaneous room temperature extrusion of $\mathrm{Pb}$ nano-whiskers from leaded brass surfaces. J Mater Res 2005, 20: 1087-1089.

[7] Zhang P, Zhang Y, Sun Z. Spontaneous growth of metal whiskers on surfaces of solids: A review. J Mater Sci Technol 2015, 31: 675-698.

[8] Liu B, Wang JY, Zhang J, et al. Theoretical investigation of $A$-element atom diffusion in $\mathrm{Ti}_{2} A \mathrm{C}(A=\mathrm{Sn}, \mathrm{Ga}, \mathrm{Cd}$, In, and Pb). Appl Phys Lett 2009, 94: 181906.

[9] Zheng W, Sun Z, Zhang P, et al. Research progress on MXene, two dimensional nano-materials. Mater Rev 2017, 31: $1-14$.

[10] Jeitschko W, Nowotny H, Benesovsky F. Die H-Phasen $\mathrm{Ti}_{2} \mathrm{TlC}, \mathrm{Ti}_{2} \mathrm{PbC}, \mathrm{Nb}_{2} \mathrm{InC}, \mathrm{Nb}_{2} \mathrm{SnC}$ und $\mathrm{Ta}_{2} \mathrm{GaC}$. Monatshefte für Chemie 1964, 95: 431-435.

[11] Wang X, Zhou Y. Solid-liquid reaction synthesis of layered machinable $\mathrm{Ti}_{3} \mathrm{AlC}_{2}$ ceramic. $J$ Mater Chem 2002, 12: 455-460.

[12] Guan C, Sun N. Synthesis of high-purity $\mathrm{Ti}_{2} \mathrm{SC}$ powder by microwave hybrid heating. $J$ Adv Ceram 2016, 5: 337-343.

[13] Sun Z, Zhou Y. Fluctuation synthesis and characterization of $\mathrm{Ti}_{3} \mathrm{SiC}_{2}$ powders. Mat Res Innovat 1999, 2: 227-231.

[14] Riley DP, Kisi EH, Wu E, et al. Self-propagating high-temperature synthesis of $\mathrm{Ti}_{3} \mathrm{SiC}_{2}$ from $3 \mathrm{Ti}+\mathrm{SiC}+\mathrm{C}$ reactants. J Mater Sci Lett 2003, 22: 1101-1104.

[15] Li S-B, Bei G-P, Zhai H-X, et al. Synthesis of $\mathrm{Ti}_{2} \mathrm{SnC}$ from $\mathrm{Ti} / \mathrm{Sn} / \mathrm{TiC}$ powder mixtures by pressureless sintering technique. Mater Lett 2006, 60: 3530-3532.

[16] Li S, Xiang W, Zhai H, et al. Formation of a single-phase $\mathrm{Ti}_{3} \mathrm{AlC}_{2}$ from a mixture of $\mathrm{Ti}, \mathrm{Al}$ and $\mathrm{TiC}$ powders with $\mathrm{Sn}$ as an additive. Mater Res Bull 2008, 43: 2092-2099.

[17] Hashimoto S, Takeuchi M, Inoue K, et al. Pressureless sintering and mechanical properties of titanium aluminum carbide. Mater Lett 2008, 62: 1480-1483.

[18] Li J-F, Matsuki T, Watanabe R. Combustion reaction during mechanical alloying synthesis of $\mathrm{Ti}_{3} \mathrm{SiC}_{2}$ ceramics from 3Ti/Si/2C powder mixture. J Am Ceram Soc 2005, 88: 1318-1320.

[19] Ge Z, Chen K, Guo J, et al. Combustion synthesis of ternary carbide $\mathrm{Ti}_{3} \mathrm{AlC}_{2}$ in Ti-Al-C system. $J$ Eur Ceram Soc 2003, 23: 567-574.

[20] Ji B, Fang P. Study on the mechanism of strengthening titanium alloys with plumbum. Vacuum 2003, 1: 40-41. (in Chinese)

[21] Guo Q, Wang G, Guo G. Common Non-Ferrous Metal Phase Diagram Atlas of F Binary Alloy. Chem Ind Press, 2010. (in Chinese)

[22] Hartman P, Perdok WG. On the relations between structure and morphology of crystals. II. Acta Cryst 1955, 8: 521-524.

[23] Liu Y, Zhang P, Ling C, et al. Spontaneous Sn whisker formation on $\mathrm{Ti}_{2} \mathrm{SnC}$. J Mater Sci: Mater Electron 2017, 28 : 5788-5795.

[24] El-Raghy T, Chakraborty S, Barsoum MW. Synthesis and characterization of $\mathrm{Hf}_{2} \mathrm{PbC}, \mathrm{Zr}_{2} \mathrm{PbC}$ and $\mathrm{M}_{2} \mathrm{SnC}(\mathrm{M}=\mathrm{Ti}$, Hf, Nb or Zr). J Eur Ceram Soc 2000, 20: 2619-2625.

[25] Barsoum MW, El-Raghy T, Farber L, et al. The topotactic transformation of $\mathrm{Ti}_{3} \mathrm{SiC}_{2}$ into a partially ordered cubic $\mathrm{Ti}\left(\mathrm{C}_{0.67} \mathrm{Si}_{0.06}\right)$ phase by the diffusion of $\mathrm{Si}$ into molten cryolite. J Electrochem Soc 1999, 146: 3919-3923.

[26] El-Raghy T, Barsoum MW, Sika M. Reaction of Al with $\mathrm{Ti}_{3} \mathrm{SiC}_{2}$ in the $800-1000{ }^{\circ} \mathrm{C}$ temperature range. Mat Sci Eng A 2001, 298: 174-178.

[27] Aldica G, Khodash V, Badika P, et al. Electrical conduction in initial field assisted sintering stages. Journal of Optoelectronics and Advanced Materials 2007, 9: 3863-3870.

[28] Li S-B, Zhai H-X, Bei G-P, et al. Synthesis and microstructure of $\mathrm{Ti}_{3} \mathrm{AlC}_{2}$ by mechanically activated sintering of elemental powders. Ceram Int 2007, 33: 169-173.

[29] Sun D, Zhou A, Li Z, et al. Corrosion behavior of $\mathrm{Ti}_{3} \mathrm{AlC}_{2}$ in molten $\mathrm{KOH}$ at $700{ }^{\circ} \mathrm{C} . J$ Adv Ceram 2013, 2: 313-317.

Open Access The articles published in this journal are distributed under the terms of the Creative Commons Attribution 4.0 International License (http://creativecommons.org/licenses/by/4.0/), which permits unrestricted use, distribution, and reproduction in any medium, provided you give appropriate credit to the original author(s) and the source, provide a link to the Creative Commons license, and indicate if changes were made. 